\section{'NuMex Centennial' and 'NuMex Twilight' Ornamental Chiles}

\author{
Paul W. Bosland ${ }^{1}$, Jaime Iglesias ${ }^{2}$, and Max M. Gonzalez ${ }^{2}$ \\ Department of Agronomy and Horticulture, New Mexico State University, Las \\ Cruces, NM 88003
}

Additional index words. Capsicum annuum, chile piquin, ornamentals, red pepper
New Mexico State Univ. Agricultural Expt. Station announces the release of 'NuMex Centennial' and 'NuMex Twilight', ornamental piquin chiles (Capsicum annuum L.) (Bosland, 1992). Fruit ripens from purple, to yellow, then to orange, and lastly to red. The various fruit colors enhance their value as commercial greenhouse pot plants. These cultivars likely will be accepted favorably by the pot plant industry. Unlike standard chile cultivars that have a dichotomous growth pattern, the polychotomous branching of the basal branches makes these new cultivars ideal for pot plant production.

\section{Description}

'NuMex Centennial' and 'NuMex Twilight' are piquin-type chiles (Bosland and Iglesias, 1992). These compact plants were developed for growing in small containers, but they are suitable for cultivation in a formal garden bed. They have one flower per leaf axil. Technically, the seed-containing pod of Capsicum is a berry, but we will use the horticultural term "fruit." The fruit are purple and ripen to yellow, orange, and then red (Fig. 1). 'NuMex Twilight' has white flowers and green ers and purple foliage. Also, the yellow fruit stage is more pronounced in 'NuMex Twilight'. Both cultivars have erect flower pedicels at anthesis, and fruit are upright and smooth with a cup-shaped calyx. Flowers begin to open 120 days after sowing, and fruit mature to red in an additional 90 days. The plants grow erect, and the stem has no pubescence. Leaf texture is smooth. Plants grown in 0.35liter pots $(102 \mathrm{~mm})$ differ from plants grown in width, and fruit length $(P \leq 0.05)$ (Table 1$)$. Both cultivars are pungent. Because they will be used only as ornamentals, their pungency level and flavor were not evaluated.

Received for publication 18 Oct. 1993. Accepted for publication 12 Apr. 1994. A contribution of the New State Univ., Las Cruces. The cost of publishing this paper was defrayed in part by the payment of page charges. Under postal regulations, this paper therefore must be hereby marked advertisement solely to indicate this fact.

${ }^{1}$ Professor.

${ }^{2}$ Research Assistant. leaves; 'NuMex Centennial' has purple flow1.25 -liter pots $(152 \mathrm{~mm})$ in plant height, plant Mexico Agricultural Expt. Station, New Mexico

\section{Origin}

During routine screening of chile germplasm for disease resistance, New Mexico Capsicum Accessions (NMCA) 10009 and NMCA 10488 were selected for potential ornamental use. 'NuMex Centenial' (NMCA 10009) and 'Nu Mex Twilight' (NMCA 10488) were originally from Chihuahua and Jalisco, Mexico, respectively. No hybridization was done. The cultivars are derived from selection within the original populations. Selection was performed for horticultural traits important to the pot plant industry. After three generations of selection, the $S_{3}$ selection, a single plant each for 'NuMex Centennial' and 'NuMex Twilight' was increased in an insect-proof greenhouse, and their uniform progeny data were recorded (Table 1).

Both cultivars have been grown commerhouse growers have noted that along with the polychotomous growth habit the four-colored fruit serve as important marketing traits. Pest problems were absent on the ornamental chiles in commercial greenhouses where standard pest control measures were followed throughmercial seed companies are offering seed of these lines in their retail catalogs.

\section{Availability}

'NuMex Centennial' and 'NuMex Twilight' are exclusively released for commercial distribution by the New Mexico Crop Improvement Association (NMCIA). Seed requests should be sent to NMCIA, New Mexico State Univ., Box 3CI, Las Cruces, NM, 88003.

\section{Literature Cited}

Bosland, P.W., 1992. Chiles: A diverse crop. HortTechnology 2(1):6-10.

Bosland, P.W. and J. Iglesias. 1992. 'NuMex Bailey Piquin' chile pepper. HortScience 27:941-942. cially in New Mexico as pot plants. Greenout the growing season. Currently, three com-

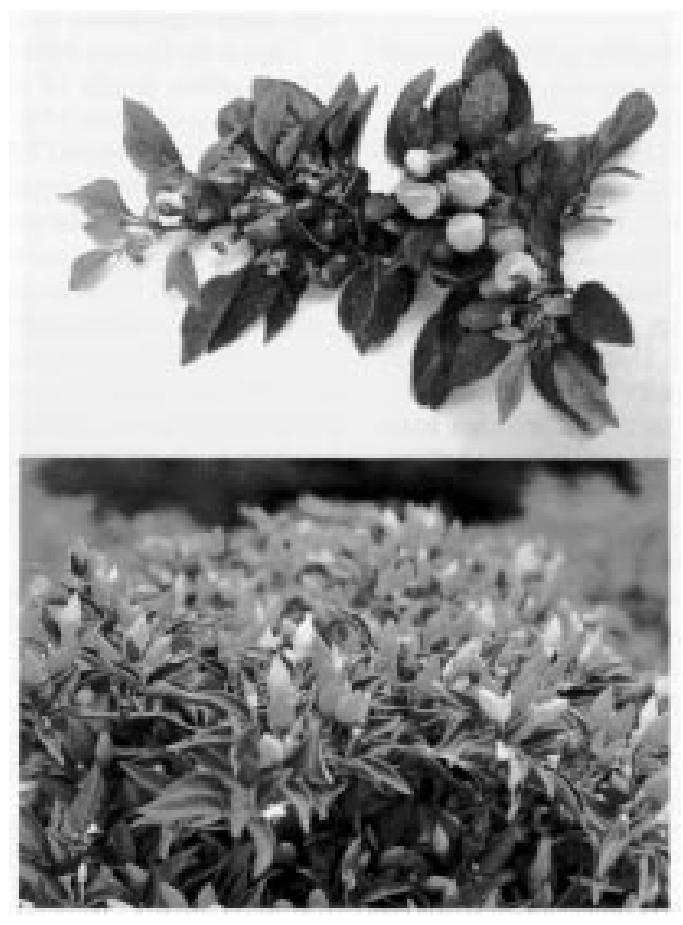

Fig. 1. 'NuMex Centennial' (top) and 'NuMex Twilight' (bottom).

Table 1. Characteristics in millimeters of 'NuMex Centennial' and 'NuMex Twilight' grown in 0.35-liter pots $(102 \mathrm{~mm})$ and 1.25 -liter pots $(152 \mathrm{~mm})$ in a greenhouse.

\begin{tabular}{|c|c|c|c|c|}
\hline \multirow[b]{3}{*}{ Plant } & \multicolumn{4}{|c|}{ Pot vol (liters) } \\
\hline & \multicolumn{2}{|c|}{0.35} & \multicolumn{2}{|c|}{1.25} \\
\hline & NuMex Centennial & NuMex Twilight & NuMex Centennial & NuMex Twilight \\
\hline 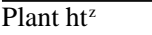 & $273 \pm 30^{y}$ & $238 \pm 33$ & $340 \pm 36$ & $301 \pm 32$ \\
\hline Plant width ${ }^{\mathrm{z}}$ & $234 \pm 29$ & $238 \pm 29$ & $354 \pm 51$ & $355 \pm 51$ \\
\hline Fruit length ${ }^{2}$ & $18.9 \pm 2.7$ & $19.1 \pm 2.7$ & $20.0 \pm 3.2$ & $21.0 \pm 3.3$ \\
\hline Fruit width & $10.0 \pm 2.2$ & $9.5 \pm 2.1$ & $12.0 \pm 1.0$ & $10.0 \pm 0.0$ \\
\hline
\end{tabular}

${ }^{2}$ Characteristics are significantly different between 102- and 152-mm pots using Student-Neuman-Keuls test at $(P \leq 0.05)$.

${ }^{y}$ All means and standard deviations calculated from 24 plants. 